\section{Commentary: Mitral valve repair using adjustable posterior leaflet neochords}

\author{
Julia Merkle-Storms, MD, and \\ Oliver J. Liakopoulos, MD
}

During past years, there has been a tremendous advancement in mitral valve repair techniques with special focus on minimally invasive strategies. ${ }^{1,2}$ The surgical "resect" approach for degenerative mitral valve diseases of the posterior or anterior leaflet was for many decades the gold standard therapy, including the classic quadrangular or triangular resections. ${ }^{3}$ Despite the good surgical results of these resection techniques, several concerns exist in terms of long-term valve competence and altered ventricular function. ${ }^{4}$ Several studies documented that posterior leaflet resection results in decreased posterior leaflet mobility, coaptation length, and increased posterior leaflet stress when compared with the nonresectional neochord technique. $^{5-7}$ In a recently published meta-analysis, implantation of neochords improved left-sided long-term ventricular function, ${ }^{8}$ but this did not reach statistical significance in a randomized controlled trial. ${ }^{9}$ On the other side, implantation of neochords is quite challenging, even for skilled surgeons. Consequently, current guidelines are still quite ambiguous toward the optimal repair approach. $^{10}$

This case series by Sotolongo and colleagues, published in this issue of the Journal, demonstrates a novel, reproducible, and easy technique of mitral valve repair using adjustable posterior leaflet neochords with excellent short-term

From the Department of Cardiothoracic Surgery, Heart Center, University of Cologne, Cologne, Germany.

Disclosures: The authors reported no conflicts of interest.

The Journal policy requires editors and reviewers to disclose conflicts of interest and to decline handling or reviewing manuscripts for which they may have a conflict of interest. The editors and reviewers of this article have no conflicts of interest.

Received for publication Dec 9, 2019; revisions received Dec 13, 2019; accepted for publication Jan 2, 2020; available ahead of print Feb 20, 2020.

Address for reprints: Oliver J. Liakopoulos, MD, Department of Cardiothoracic Surgery, Heart Center of the University of Cologne, Kerpener Strasse. 62, 50924 Cologne, Germany (E-mail: oliver.liakopoulos@uk-koeln.de).

JTCVS Techniques 2020;2:56-7

2666-2507

Copyright $(2020$ The Authors. Published by Elsevier Inc. on behalf of The American Association for Thoracic Surgery. This is an open access article under the CC BY-NCND license (http://creativecommons.org/licenses/by-nc-nd/4.0/).

https://doi.org/10.1016/j.xjtc.2020.01.022

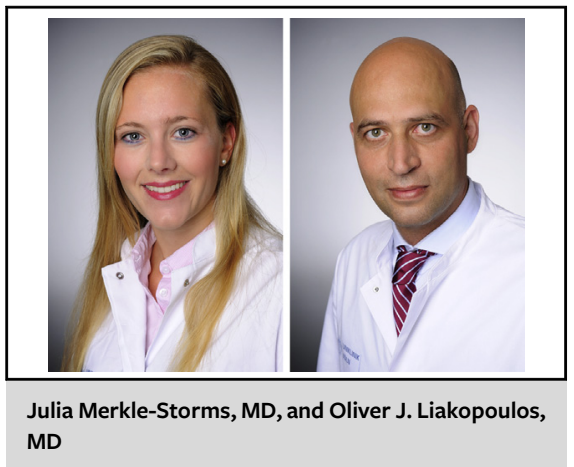

CENTRAL MESSAGE

This case series demonstrates a

novel, reproducible, and

straightforward technique for

minimally invasive mitral valve

repair using adjustable neo-

chords with excellent short-term

results.

results. ${ }^{11}$ In contrast to the traditional loop technique, where static lengths of neochords are chosen after measurements with or without a caliper, the introduced technique enables a flexible and reproducible adjustment of length by the surgeon. As depicted in the Central Picture of their report, the looped neochords are secured behind the mitral annulus and on the left atrial side. Thus, final visual correction of leaflet prolapse and valve incompetence can be performed safely after annuloplasty during pressurization of the left ventricle with saline. Although several neochord implantation techniques have been described in the literature before, the strength of the introduced technique lies in its reproducible, straightforward fashion that makes it suitable for minimally invasive approaches Furthermore, the group from Yale report in their surgical experience of this small case series excellent short-term echocardiographic and clinical results that support the preliminary safety and efficacy of this approach. Nonetheless, long-term results and larger cohorts are needed to allow a final interpretation of the adjustable chord technique.

\section{References}

1. Suri RM, Dearani JA, Mihaljevic T, Chitwood WR Jr, Murphy DA, Trento A, et al. Mitral valve repair using robotic technology: safe, effective, and durable. J Thorac Cardiovasc Surg. 2016;151:1450-4.

2. Javadikasgari H, Suri RM, Tappuni B, Lowry AM, Mihaljevic T, Mick S, et al. Robotic mitral valve repair for degenerative posterior leaflet prolapse. Ann Cardiothorac Surg. 2017;6:27-32. 
3. Nishimura RA, Otto CM, Bonow RO, Carabello BA, Erwin JP III, Fleisher LA, et al. 2017 AHA/ACC focused update of the 2014 AHA/ACC guideline for the management of patients with valvular heart disease: a report of the American College of Cardiology/American Heart Association task force on clinical practice guidelines. Circulation. 2017;135:e1159-95.

4. Choi A, McPherson DD, Kim H. Neochordoplasty versus leaflet resection for ruptured mitral chordae treatment: virtual mitral valve repair. Comput Biol Med. 2017;90:50-8.

5. Padala M, Powell SN, Croft LR, Thourani VH, Yoganathan AP, Adams DH. Mitral valve hemodynamics after repair of acute posterior leaflet prolapse: quadrangular resection versus triangular resection versus neochordoplasty. $J$ Thorac Cardiovasc Surg. 2009;138:309-15.

6. Morgan AE, Pantoja JL, Grossi EA, Ge L, Weinsaft JW, Ratcliffe MB. Neochord placement versus triangular resection in mitral valve repair: a finite element model. J Surg Res. 2016;206:98-105.

7. Paulsen MJ, Imbrie-Moore AM, Wang H, Bae JH, Hironaka CE, Farry JM, et al. Mitral chordae tendineae force profile characterization using a posterior ventricular anchoring neochordal repair model for mitral regurgitation in a three- dimensional-printed ex vivo left heart simulator. Eur J Cardiothorac Surg. 2020;57:535-44.

8. Mazine A, Friedrich JO, Nedadur R, Verma S, Ouzounian M, Juni P, et al. Systematic review and meta-analysis of chordal replacement versus leaflet resection for posterior mitral leaflet prolapse. J Thorac Cardiovasc Surg. 2018;155: 120-8.e10.

9. Falk V, Seeburger J, Czesla M, Borger MA, Willige J, Kuntze T, et al. How does the use of polytetrafluoroethylene neochordae for posterior mitral valve prolapse (loop technique) compare with leaflet resection? A prospective randomized trial. J Thorac Cardiovasc Surg. 2008;136:1205; discussion -6.

10. Nishimura RA, Otto CM, Bonow RO, Carabello BA, Erwin JP III Fleisher LA, et al. 2017 AHA/ACC focused update of the 2014 AHA/ ACC Guideline for the management of patients with valvular heart disease: a report of the American College of Cardiology/American Heart Association task force on clinical practice guidelines. J Am Coll Cardiol. 2017;70 252-89.

11. Sotolongo A, Mahmood SUB, Vaccaro B, Geirsson A. Mitral valve repair using adjustable posterior leaflet neochords. J Thorac Cardiovasc Surg Tech. 2020;2:50-4. 